\title{
Foreword: Enabling and empowering inclusive societies
}

Electoral democracies don't know how to 'represent' migrants. Human rights struggles have been won in claims to equal citizenship: by industrial workers, women, Aboriginals, detainees, gays and lesbians. Persons with disabilities knew that, when they started organizing, their voice could carry, because their vote could punish or reward politicians. Although much still needs to be done, politicians started to pay attention and change their language, their behaviour, their conceptions, in turn changing the perceptions of the electorate.

For the most part, this is not happening for migrants and will not happen in the near future: migrants can vote nowhere in national elections. The right to vote and be elected is reserved, even in international human rights law, to citizens.

In electoral democracies, politicians govern themselves according to electoral incentives. It is the best system yet invented to govern ourselves. But we are facing a structural limit of electoral democracy. For those who are not represented, rights are not respected, protected and promoted in the political system.

At present, no politician has any incentive to say anything good about migrants. Nationalist populist politicians continue to say that migrants steal jobs, create insecurity or change our values - all assertions which have been proven wrong by social science - with total impunity. In most countries, mainstream politicians are not taking the electoral risk of picking a fight in favour of persons who are politically non-existent.

In fact, mainstream political parties everywhere have been at a loss in finding ways to contradict the fantasies, threats and stereotypes of the nationalist populist discourse. Strategic advisors will advise against taking a long-term principled stand on such issues, if it threatens short-term electoral gains. Many governments have restricted the rights of migrants generally and of refugees in particular. Access to labour markets and to justice, to take only two examples, have been made markedly more difficult.

The situation is compounded when other characteristics increase the 
social isolation and political marginalization of certain categories of migrants. Migrant women, migrant children, elderly migrants, asylum seekers, refugees, migrants belonging to certain minorities - and migrants with disabilities - may find themselves in even more complex situations.

Refugees benefit from a special status, guaranteed by the 1951 Geneva Convention, but states tend to restrict access to that status and favour providing temporary or subsidiary protection. Access to appeals or judicial review has been limited. And refugee status in many countries no longer guarantees access to permanent residence and to citizenship.

As this book well explains, refugees with disabilities live in a state of permanent marginalization. The extraordinary agency and courage that they demonstrate through their life trajectory are met most often with administrative roadblocks and social obstacles which are difficult to overcome without the help of the social and family networks which might have been available in the home country. Their social capital gone, they find themselves socially isolated. Very often, government-based support mechanisms in the host country are either unavailable or woefully inadequate for their specific predicament.

In Chapter 1, the authors state:

The practical import of the definition of disability in Article 1 of [the CRPD] is the acknowledgement that impairments alone do not create disability. Rather, it is the failure to accommodate, to adapt and assist that 'disables'.

Mutatis mutandis, they could be talking about migrants who can be 'citizens' in the sense that they live, work, obey the law and pay taxes for years in a country, but do not benefit from the attributes of 'Citizenship', i.e. the right to vote and be elected and the right to enter and stay in the country. These people are politically disempowered by the failure to incorporate them in the body politic. Refugees, as a specific category of migrants, are even further disadvantaged, deprived as they are of an effective nationality and always at risk of return or refoulement, the consequence of which can be tragic.

Being at the same time disabled, disempowered and 'de-nationalized' compounds markers of marginalization. Only a collective response by the host society in the form of an enabling policy environment and technical empowerment mechanisms can provide refugees with disabilities with the kind of tools they need to ensure that their voice is heard and their rights protected.

There are no easy solutions. Mobility and diversity create complex issues which require sophisticated policies, long-term vision, targeted 
investments and nuanced discourses. In the past 20 years, with a few exceptions, we have been treated with none of the above. We urgently need strong integration policies, efficient equality and anti-discrimination mechanisms, a good fight against hate speech, access to justice for all, and the promotion of diversity at all levels. Only then can we ensure that migrants, regardless of status, become active citizens.

I suggest that, at some point in the future, we may need to attach the right to vote to forms of residency. If one pays taxes and is subject to the law for some time, one should have a say in how the laws are adopted and how the taxes are spent. 'No taxation without representation', was a cry of the American revolutionaries. However, I cannot see that this will happen any time soon. Perceptions of migrants, whatever their characteristics, will likely remain negative.

We need all migrants to be empowered to defend their own rights, politically and judicially, and to express their 'lived experience' in their own words. For that, we need to shun the legal, political and social precariousness which silence them, and provide them with secure status as migrants, as workers, as refugees, as 'citizens' (with a small 'c'), i.e. as persons who live in the 'city' and share a common destiny with all other 'citizens'.

Despite isolated good practices such as the attitude of Mayor de Blasio towards 'all New Yorkers', we are still missing the mark by a considerable margin for lack of a credible political relay. We are pushing many migrants into the underground or the semi-underground, disempowering them and thus creating opportunities for exploitation and markets for mafias.

Refugees with disabilities, like many other migrants, demonstrate extraordinary agency. For their benefit, but also for the benefit of the societies in which they live, we need to support this agency and create pathways to empowerment, limiting discrimination in the implementation of social inclusion policies, ensuring effective access to justice for all (including adequate legal representation and interpretation during refugee status determination and other legal procedures), and providing enabling social and political environments which allow their voice to be heard and count.

Our colleagues Crock, Smith-Khan, McCallum and Saul sum up in this book the realizations of a remarkable research project on the intersectionality of refugee status and disability. The analysis of many aspects of the trajectory of refugees with disabilities - including the CRPD as a game changer, humanitarian assistance, interdiction and detention, refugee status determination, access to economic and social rights, and implementation strategies - is thorough and rigorous, and the fieldwork adds 
considerable depth to the narrative. This book will remain the reference on the issue for years to come.

Prof. François Crépeau

United Nations Special Rapporteur on the Human Rights of Migrants

Director, McGill Centre for Human Rights and Legal Pluralism Hans \& Tamar Oppenheimer Professor in Public International Law McGill University 